\title{
Analysis of Midgut Bacterial Community Structure of Neanthes chilkaensis from Polluted Mudflats of Gorai, Mumbai, India
}

\author{
Anoop R. Markande', Aram Mikaelyan', Binaya Bhusan Nayak ${ }^{1}$, Ketan D. Patel ${ }^{2}$, \\ Niyati B. Vachharajani1, Alagarsamy Vennila1, Kooloth Valappil Rajendran1, \\ Chandra S. Purushothaman' ${ }^{1}$ \\ ${ }^{1}$ Central Institute of Fisheries Education, Mumbai, India \\ ${ }^{2}$ Department of Microbiology and Biotechnology Centre, Faculty of Science, The Maharaja Sayajirao \\ University of Baroda, Vadodara, India \\ Email: ${ }^{\text {nayakbb@gmail.com }}$
}

Received 29 April 2014; revised 27 May 2014; accepted 25 June 2014

Copyright (C) 2014 by authors and Scientific Research Publishing Inc.

This work is licensed under the Creative Commons Attribution International License (CC BY).

http://creativecommons.org/licenses/by/4.0/

(c) (i) Open Access

\begin{abstract}
Adaptation of microbial communities to anthropogenic stress has often been shown to involve reduction in diversity and in selective enrichment of species capable of survival. The gut bacterial community of pollution-stressed polychaete Neanthes chilkaensis was studied using cultivation dependent and independent approaches. The possible role of the gut bacteria in remediation of pollutants was also studied. The analysis of clones covering about $90 \%$ of the $16 \mathrm{~S}$ rRNA clone library indicated that the majority of the taxa in the library resemble GenBank entries of aromatichydrocarbon pollutant degraders. Among them Firmicutes and Actinobacteria were dominant. About $84 \%$ of the gut isolates were capable of utilizing PAHs as sole carbon sources while $20 \%$ of isolates were found to produce biosurfactants. Production of surfactant along with capability to utilize PAH and other pollutants indicate the role of the gut community in alleviating the pollution stress. The results also show the potential source of microorganisms with industrial and environmental application.
\end{abstract}

\section{Keywords}

Deposit Feeder, Polycheate, Nereid, Anthropogenic Stress, Gut Microbiota, Biosurfactant

\footnotetext{
${ }^{*}$ Corresponding author.

How to cite this paper: Markande, A.R., Mikaelyan, A., Nayak, B.B., Patel, K.D., Vachharajani, N.B., Vennila, A., Rajendran, K.V. and Purushothaman, C.S. (2014) Analysis of Midgut Bacterial Community Structure of Neanthes chilkaensis from Polluted Mudflats of Gorai, Mumbai, India. Advances in Microbiology, 4, 906-918. http://dx.doi.org/10.4236/aim.2014.413101
} 


\section{Introduction}

Many benthic invertebrates can survive in organically-enriched waters, and are often considered as indicators of pollution [1]. Deposit feeders like nereids live and feed directly on recently deposited sediments, and therefore, are constantly exposed to pollutants [2]. Nereids are the polychetes belonging to phylum Annelida abundant in all environments of the world's oceans notably successful in mud and sand habitats [3]. The microbial community in the gut of these animals undergoes specific changes to strengthen members that are capable of tolerating and possibly metabolizing toxic compounds encountered by the host gut [4] [5], and thereby contributing to detoxification of this micro environment. In this process certain groups of bacteria in the gut get selected or rejected depending upon their ability to survive the exposure to pollutants [6] [7]. Li et al. [8] described these remarkable changes in the microbial communities of foregut, midgut and hindgut of Neanthes sp. [7]. Though few attempts have been made to understand these bacterial communities using culture based methods [8] [9], the relative difficulty in simulating growth conditions of the gut necessitates the use of cultivation-independent methods, in addition to culture based methods. Here we have employed both culture dependent and independent method to understand the bacterial communities in the gut of the Neanthes chilkaensis (Southern, 1921), a polychaete commonly found in the Indian Ocean. The physiological properties of the samples of the nereid isolation were similar to those as described by Vijay et al. [10] and Jaiswar et al. [11]. The culturable gut isolates were checked for their ability to degrade common pollutants which are known to find their way to Gorai mudflat due to idol immersion [12], from ferries [13] or from the industrial belt located upstream. The results here emphasize the need for studying the micro flora inhabiting various benthic fauna with potential in environmental and industrial applications.

\section{Materials and Methods}

\subsection{Sampling of Animals}

Wild Neanthes chilkaensis specimens were collected from the Gorai mudflats $\left(19^{\circ} 14^{\prime} 0^{\prime \prime N}\right.$; $\left.72^{\circ} 49^{\prime} 25^{\prime \prime} \mathrm{E}\right)$ from a depth of around 5 - $10 \mathrm{~cm}$. The worms were transported in Gamma-sterilized Uricol bottles (HiMedia Laboratories, India) along with native sediment and water. This species could not be found in any other unpolluted sampling locations sampled by us for sediments and water.

\subsection{Preparation of Nereid Gut Homogenate}

Six mature specimens were randomly chosen from a collected lot of around sixty individuals. Six specimens were placed in a sterile petri dish containing roughly $30 \mathrm{ml}$ filter-sterilized $(0.22 \mu \mathrm{m}$ PVDF membrane, Millipore, France) seawater for 24 hours to allow them to empty their gut contents. While six individuals were placed in a Petri dish containing sterile distilled water for $1 \mathrm{~h}$ with water change every $10 \mathrm{~min}$. The worms were starved for $24 \mathrm{~h}$ and were then washed in sterile physiological saline $(0.85 \% \mathrm{NaCl})$, surface sterlized in $2 \%$ hypochloric acid [14], rinsed again with saline and pinned to a sterile cork dissection pad. A fine ventral incision was made about $5 \mathrm{~mm}$ from the head continuing up to the tail using a sterile surgical blade, with careful separation of the gut from skin and connective tissue. The worms were rinsed periodically with sterile saline to keep the tissue hydrated. The isolated midgut sections were homogenized in sterile saline using micro-pestles (HiMedia Laboratories). Halves of the midgut homogenates from each of the six specimens were used for total DNA isolation and the other halves were used for culturable studies. Both aspects of the study were conducted simultaneously.

\subsection{Isolation of Bacterial Flora from the Midgut Homogenates}

One-hundred microlitre each of ten-fold dilutions made in physiological saline, of the six midgut homogenates was spread-plated on Nutrient Agar (HiMedia Laboratories) prepared in sterile aged sea water (adjusted to pH 5, 7 and 8 individually in triplicates) prepared as given before. Plates were incubated aerobically for ten days at $25^{\circ} \mathrm{C}$ and the colonies grown were selected on the basis of colony characteristics. Representative colonies isolated from the gut were preserved in glycerol stocks at $-80^{\circ} \mathrm{C}$ for further analysis.

\subsection{DNA Extraction}

The isolates obtained from midgut homogenates were grown in tubes containing $5 \mathrm{ml}$ of Nutrient Broth (HiMedia Laboratories), prepared in sea water at $30^{\circ} \mathrm{C}$ for 48 hours. The bacterial cells were pelleted by centrifugation 
(6000 $\times \mathrm{g}$ for $5 \mathrm{~min})$ and DNA was extracted using the method proposed by Neumann et al. [15]. Community DNA from the midgut of $N$. chilkaensis the DNEasy Blood and Tissue Kit (Qiagen, Germany) was used with the protocol modified for maximum recovery of DNA from Gram-positive bacteria, as per the manufacturer's instructions. The quality of the preparations was checked by agarose electrophoresis.

\subsection{DGGE Analysis and the Selection of N. chilkaensis Host for Study}

Out of the six $N$. chilkaensis hosts selected, only one host was used for thorough investigation. This was done by first comparing the Denaturing Gradient Gel Electrophoresis (DGGE) profiles of 16S rDNA amplicon of the mid-gut bacterial community of six hosts and then selecting the consensus one. Touchdown PCR was used to amplify the eubacterial hypervariable region V3, of the 16S rRNA gene using 338F (5'-ACTCCTACGGGAGGCAGCAG-3') and 518-GC (5-ATTACCGCGGCTGCTGG CGCCCGCCGCGCGCGGCGGGCGGGGCGGGGGCACGGGGGG-3') [16]. The PCR reaction mixtures (50 $\mu \mathrm{l})$ contained 50 - 100 ng of template DNA, 200 $\mu \mathrm{M}$ of each dNTP, $10 \mathrm{mM}$ of each primer, $10 \%$ of $10 \times$ Taq Buffer, $25 \mathrm{mM} \mathrm{MgCl}_{2}, 1.5$ units of Taq DNA polymerase (Bangalore GeNei, India) and sterile deionized water (Milli-Q). The touchdown PCR conditions were $94^{\circ} \mathrm{C}$ for $2 \mathrm{~min} ; 20$ cycles of $94^{\circ} \mathrm{C}$ for 30 sec followed by a $62^{\circ} \mathrm{C}-57^{\circ} \mathrm{C}$ touchdown for 30 sec and $72^{\circ} \mathrm{C}$ for 1 min. This was followed by 10 cycles of the same temperature steps with the touchdown replaced with a constant annealing temperature of $57^{\circ} \mathrm{C}$ for $30 \mathrm{sec}$. The above program was followed by a final extension for $15 \mathrm{~min}$ at $72^{\circ} \mathrm{C}$. DGGE gels were run on the DCode electrophoresis unit (BIO-RAD, Singapore). For each sample, $400 \mathrm{ng}$ of the PCR product was loaded on a $1-\mathrm{mm}$ thick, $10 \%$ polyacrylamide gel containing $40 \%$ to $70 \%$ gradient of denaturant (urea and formamide). Electrophoresis was carried out for $18 \mathrm{hrs}$ at $70 \mathrm{~V}$, in $1 \times$ TAE buffer, at a constant temperature of $60^{\circ} \mathrm{C}$. The gels were silver-stained and visualized in white light (DNR Bio-Imaging Systems, Israel). DGGE fingerprints obtained from the six individuals were compared using the Renkonen index [17] of similarity, a percentage based measure of overlap between communities, using the Community Analysis Package 4.0 (Pisces conservation Ltd., UK), which is defined as

$$
\mathrm{P}=\sum \min \left(p_{1 i}, p_{2 i}\right)
$$

where, $\mathrm{P}$ is the similarity between community 1 and $2 . p_{1 i}$ is the proportion of group $i$ in $1 ; p_{2 i}$ is the proportion of group $i$ in 2 .

The individual bands representing distinct clones were carefully dissected from the gel, purified using QIAquick Gel Extraction Kit (Qiagen) and the elutes were preserved at $-20^{\circ} \mathrm{C}$ for further analysis. One of the samples, selected to represent the common DGGE banding pattern, was continued with cultivation-independent analyses, and its isolates were taken for cultivation-dependent studies.

\subsection{PCR Amplification of the 16S rRNA Genes}

Eubacterial primer set 63f (5'-CAG GCC TAA CAC ATG CAA GTC-3') and 1387r (5'-GGG CGG WGT GTA CAA GGC-3') [18] were used to amplify 16S rRNA genes from isolates and midgut total DNA with a QB96 Thermocycler (Quanta Biotech, UK). The thermal cycling conditions followed were initial denaturation at $94^{\circ} \mathrm{C}$ for $4 \mathrm{~min}$; 30 cycles of $94^{\circ} \mathrm{C}$ for $30 \mathrm{~s}, 57^{\circ} \mathrm{C}$ for $30 \mathrm{sec}$ and $72^{\circ} \mathrm{C}$ for $1 \mathrm{~min} 30 \mathrm{sec}$ and a final extension step of $72^{\circ} \mathrm{C}$ for $30 \mathrm{~min}$. The amplified products were eluted using the QIAquick Gel Extraction Kit (Qiagen). The eluates were cloned using the same method described below, sent for sequencing to Bangalore GeNei, Bengaluru, India, and sequences were checked against the GenBank database using the NCBI-BLAST program.

\subsection{Construction of the $16 \mathrm{~S}$ rRNA Gene Clone Library}

The eluted $\sim 1.3 \mathrm{~kb}$ amplicons obtained from the midgut community DNA, were cloned (in duplicate) into the pTZ57R/T vector (Fermentas, USA) according to the manufacturer's instruction, and transformed into Escherichia coli $\mathrm{DH} 5 \alpha$, using the InsTA-cloning kit (Fermentas). The presence of the inserts in the colonies was checked by PCR using M13 standard sequencing primers (Fermentas). The amplicons obtained were digested using HaeIII and HpaII (Fermentas) and screened by Amplified rDNA Restriction Analysis (ARDRA) in order to avoid sequencing of redundant clones. Multiple representatives of each ARDRA group were selected and sequenced commercially (Bangalore GeNei). 


\subsection{Phylogenetic Analysis of the 16S rRNA Gene Clone Library}

Single parse sequence analysis with approximately 700 - 850 base reads were corrected using the Chimera Check program at the RDP website (http://rdp.cme.msu.edu/). The partial 16S rRNA gene sequence reads from the cultivation-dependent and independent studies were compared against the submissions available in GenBank (NCBI), using the BLAST algorithm [19]. Phylogenetic analyses were conducted using the MEGA4 Package [20] and the ClustalW interface of MEGA4 was used to make multiple alignments. The evolutionary history was inferred using the Neighbour-Joining method [21]. Homologous regions of 560 bp (position 93 to 653), corresponding to the V2-V3 region in E. coli ATCC $11775 \mathrm{~T}$ were used for phylogenetic analysis based on the understanding that phylogenetic trees constructed using partial sequences have comparable topologies with those constructed using full sequences [22] [23]. From phylogenetic tree, operational taxonomic units (OTUs) were studied.

\subsection{Abilities of the Isolates to Utilize Recalcitrant Aromatic Compounds as a Sole Carbon Source}

The isolates were checked for their ability to utilize the following polyaromatic hydrocarbons (PAHs) like benz $(\mathrm{k})$ fluoranthene $(\mathrm{B}(\mathrm{k}) \mathrm{F})$, benz $(\mathrm{k})$ pyrene $(\mathrm{B}(\mathrm{k}) \mathrm{P})$, chrysene $(\mathrm{CHY})$, dibenz(a,h)anthracene $(\mathrm{DBA})$, fluorene (FLU), naphthalene (NAF), phenanthrene (PHE) and pyrene (PYR). The PAHs were supplemented in mineral media as sole carbon sources. $250 \mu \mathrm{l}$ of each of the filter sterilized $0.4 \%$ polyaromatic hydrocarbons made in dimethylformamide (DMF) were spread separately on the surface of MM1 agar (containing $\left(\mathrm{L}^{-1}\right), 2.92 \mathrm{~g} \mathrm{KH}_{2} \mathrm{PO}_{4}$; $1.51 \mathrm{~g} \mathrm{~K}_{2} \mathrm{HPO}_{4} ; 1.0 \mathrm{~g}\left(\mathrm{NH}_{4}\right)_{2} \mathrm{SO}_{4} ; 2.02 \mathrm{~g} \mathrm{CaCl}_{2} \cdot 2 \mathrm{H}_{2} \mathrm{O} ; 2.26 \mathrm{~g} \mathrm{Na}_{2} \mathrm{HPO}_{4} \cdot 7 \mathrm{H}_{2} \mathrm{O} ; 20 \mu \mathrm{g} \mathrm{FeCl} \cdot 6 \mathrm{H}_{2} \mathrm{O} ; 3.12 \mathrm{~g}$ $\mathrm{MgSO}_{4} \cdot 7 \mathrm{H}_{2} \mathrm{O}$ and $20 \mathrm{~g}$ of agar) plates [24]. To rule out the DMF degradation by the bacteria, the isolates were also streaked on control plates with $250 \mu \mathrm{l}$ DMF spread on it. 2,4,6-trichlorophenol (TCP) utilization was checked using basal liquid medium (MM2) (containing $\left(\mathrm{L}^{-1}\right) 0.5 \mathrm{~g} \mathrm{H}_{3} \mathrm{BO}_{3} ; 0.4 \mathrm{~g} \mathrm{ZnSO} \cdot 7 \mathrm{Z}_{2} \mathrm{O} ; 0.4 \mathrm{~g}$ $\mathrm{MnSO}_{4} \cdot \mathrm{H}_{2} \mathrm{O} ; 0.2 \mathrm{~g} \mathrm{FeCI}_{3} 6 \mathrm{H}_{2} \mathrm{O} ; 0.2 \mathrm{~g}\left(\mathrm{NH}_{4}\right) 2 \mathrm{MoO}_{4} ; 0.1 \mathrm{~g} \mathrm{KI}$; and $\left.0.04 \mathrm{~g} \mathrm{CuSO}_{4} \cdot 5 \mathrm{H}_{2} \mathrm{O}\right)$ [25]. $250 \mu \mathrm{l}$ of filter-sterilized $1 \%$ stock of TCP made in $0.2 \mathrm{~N} \mathrm{NaOH}$, was added aseptically to $20 \mathrm{ml}$ of autoclaved MM2 to serve as the sole carbon source. About $10^{8}$ cells of each of the isolates were inoculated in this medium and were incubated at $25^{\circ} \mathrm{C}$ for three weeks. Turbidity suggested the growth of the organism. The inference was confirmed by observing growth on MM2 agar plates along with TCP. Isolates capable of utilizing TCP as the sole carbon source could also grow without the biotin supplement.

\subsection{Assay for Surfactant Tolerance and Production}

Isolated bacteria were assayed for surfactant resistance according to Plante et al. [9] using CTAB and Triton-X100 just above the general toxic level for microorganisms. Hemolysis was used as an initial screening criterion for biosurfactant-production by the isolates. The isolates were streaked on Blood Agar (HiMedia Laboratories) and incubated at $30^{\circ} \mathrm{C}$ for 48 hours after which they were checked for hemolysis. Since hemolysis is only a suggestive method for studying biosurfactant production by bacteria [26], surface tension was measured for each isolate using a surface tensiometer (Khushboo Scientific, India) employing the DuNouy's platinum-ring method. The bacterial isolates were grown in 250-ml Erlenmeyer flasks, in triplicates, containing $50 \mathrm{ml}$ LuriaBertani broth (HiMedia Laboratories) at $30^{\circ} \mathrm{C}$ on a rotary shaker $(180 \mathrm{rpm})$ for 24 hours. The cultures were centrifuged $(8000 \times \mathrm{g})$ for $10 \mathrm{~min}$ and cell-free supernatants were checked for the reduction in the surface tension at room temperature. Emulsification index (\% EI) of the supernatants was calculated by the method described by Markande et al. [27] using the formula

$$
\text { Emulsificationindex }(\% E I)=\frac{\text { Height of the emulsion }}{\text { Total height of the mixture }} \times 100
$$

\section{Results}

\subsection{Bacterial Communities in the Mid Gut of $N_{\text {. }}$ chilkaensis Hosts}

The DGGE banding patterns (Figure 1) obtained for the gut bacterial community of the six N. chilkaensis individuals were highly similar indicating a regular bacterial community being native to the specimens. The similarities are further evident from the Renkonen indices (Table 1). The sample No 2 was selected as a representative sample for furthering detailed analysis. 


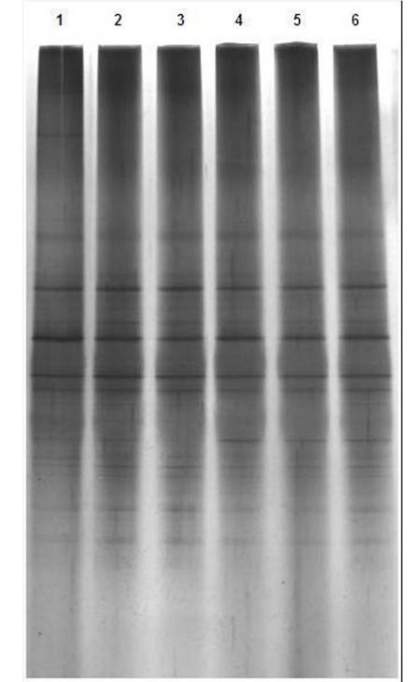

Figure 1. Denaturing gradient Gel Electrophoresis (DGGE) profiles of V3 region of six different $N$. chilkaensis midgut samples. Lanes are labeled with midgut sample numbers.

Table 1. Renkonen indices for midgut bacterial community similarity between different $N$. chilkaensis hosts.

\begin{tabular}{ccccccc}
\hline \multirow{2}{*}{ Sample $^{\mathbf{a}}$} & \multicolumn{7}{c}{ Renkonen Index } \\
\cline { 2 - 6 } & Wm1 & Wm2 & Wm3 & Wm4 & Wm5 & Wm6 \\
\hline Wm1 & - & - & - & - & - & - \\
Wm2 & 0.81 & - & - & - & - & - \\
Wm3 & 0.81 & 0.84 & - & - & - & - \\
Wm4 & 0.71 & 0.79 & 0.72 & - & - & - \\
Wm5 & 0.62 & 0.74 & 0.67 & 0.88 & - & - \\
Wm6 & 0.86 & 0.89 & 0.79 & 0.79 & 0.74 & - \\
\hline
\end{tabular}

${ }^{\mathrm{a}} \mathrm{Wm} 1, \mathrm{Wm} 2, \mathrm{Wm} 3, \mathrm{Wm} 4, \mathrm{Wm} 5, \mathrm{Wm} 6$ represent midguts isolated from six N. chilkaensis individuals.

The nutrient agar plates having different $\mathrm{pH}$ were carefully observed for colonies. All the isolates picked up could be grouped into 13 colony morphotypes. All these representative morphotypes were identified by sequencing of 16S rRNA gene and BLAST analysis. The isolates were largely firmicutes, the majority of which fell within the genus Bacillus (Table 2). The sequences from few of the isolates matched at varying percentages with a PAH-degrading Bacillus sp. (98.4\% to 99.8\%). While sequence from isolate GNG-AV15 matched to that of a Staphylococcus sp., GNG-AV13 matched a Kytococcus sequence (Table 2).

\subsection{Phylogenetic Analysis of 16S rRNA Clone Library}

A total of 108 clones were found to be positive for the 1.3-kb insert. The patterns obtained from ARDRA were used to construct a dendrogram wherein the 108 clones were grouped into eight large ARDRA clusters. From each group, a minimum of two and a maximum of eight clones were selected for sequencing. ARDRA branches represented by single clones were also sequenced. A total of 49 clones were analyzed by Single Parse Analysis, of which two were revealed as possible chimeras. This left 47 representatives of the original 108 clones. The clone coverage could, thus, be calculated by Good's formula [28] for the 12 taxa (Table 3 and Figure 2) among the original 108 clones. The coverage was found to be 90 percent, which means that there was a 10 percent chance that the 109th clone would yield a new OTU. Four clones in the original library were present as single copies and contributed to some loss of coverage.

The diversity observed among isolates and clones spans across many phyla, including Proteobacteria, Firmicutes and Actinobacteria. The 16S rRNA gene sequences from the isolates and clones were aligned with their 
Table 2. Phylogenetic affiliation of isolates frome midgut of $N$. chilkaensis.

\begin{tabular}{cccc}
\hline $\begin{array}{c}\text { Isolate Name } \\
\text { (Accession Number) }\end{array}$ & Description & Closest Taxon & \\
\hline GNG-AV1 (FJ966097) & Greenwater aquaculture system Bacillus sp. Isolate & Accession Number & Similarity (\%) \\
\hline GNG-AV4 (FJ966098) & PAH degrading Bacillus sp. isolate & FJ842658 & 100.0 \\
GNG-AV5 (FJ966099) & Greenwater aquaculture system Bacillus sp. Isolate & FJ449840 & 99.3 \\
GNG-AV6 (FJ966100) & PAH degrading Bacillus sp. & FJ660932 & 99.5 \\
GNG-AV7 (FJ966101) & PAH degrading Bacillus sp. & FJ660932 & 99.8 \\
GNG-AV8 (FJ966102) & Bacillus sp. associate of marine sponge, Halichondria rugosa & EF370053 & 99.6 \\
GNG-AV9 (FJ966103) & PAH degrading Bacillus sp. & FJ449840 & 98.0 \\
GNG-AV10 (FJ976468) & Greenwateraquaculture system Bacillus sp. Isolate & FJ660932 & 97.2 \\
GNG-AV11 (FJ966104) & Greenwater aquaculture system Bacillus sp. Isolate & FJ660932 & 99.3 \\
GNG-AV12 (FJ966105) & PAH degrading Bacillus sp. & FJ449840 & 98.7 \\
GNG-AV13 (FJ966106) & Kytococcus sp. isolate from Nyctiphanes simplex gut & EU090136 & 99.2 \\
GNG-AV14 (FJ966107) & Uncultured bacterium clone from oyster shell & EU369170 & 100.0 \\
GNG-AV15 (FJ966108) & Staphylococcus isolate from Calcinus obscurus gut & EU246837 & 99.8 \\
\hline
\end{tabular}

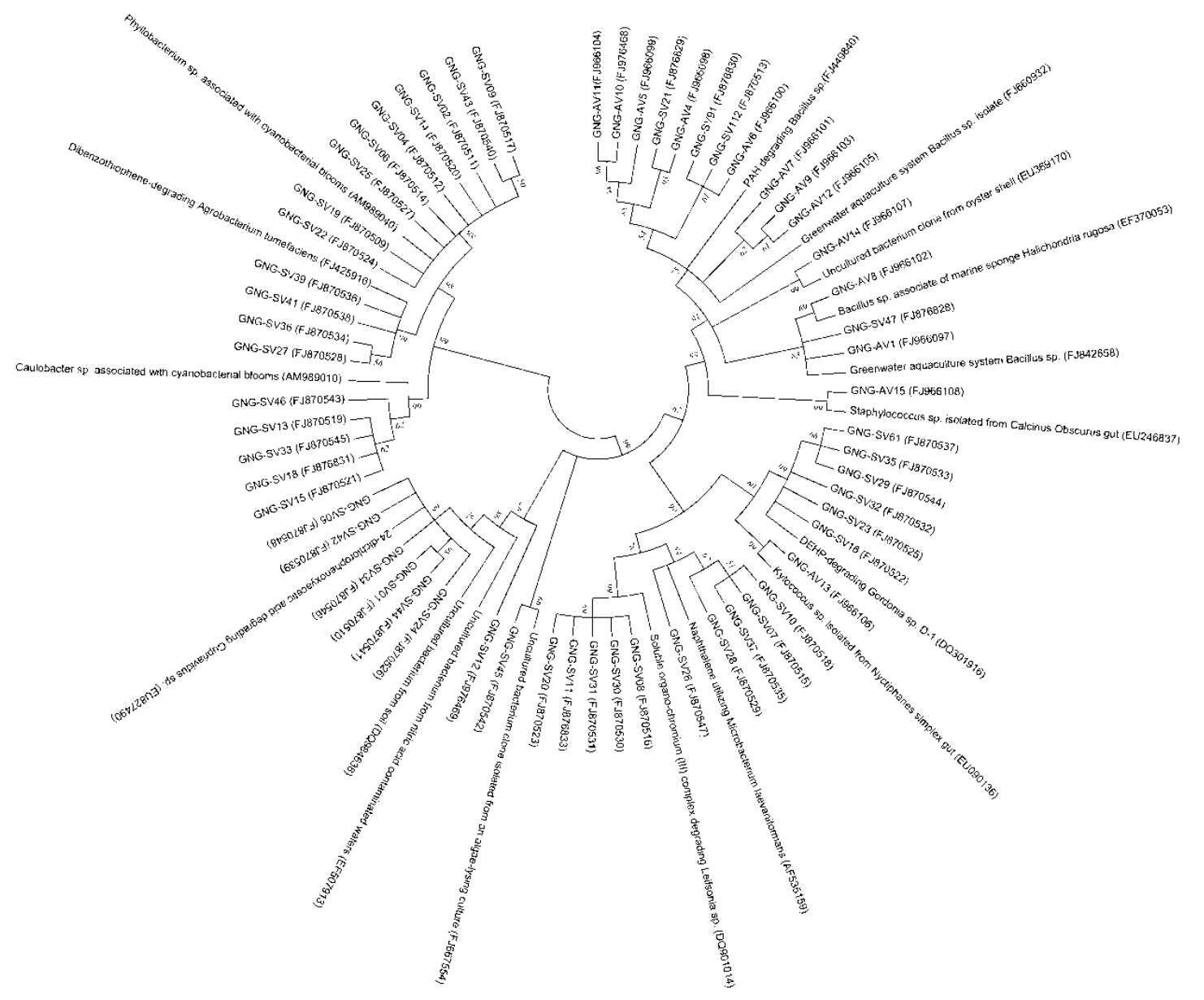

Figure 2. Phylogenetic affiliations of the members of the bacterial community residing in the midgut of $N$. chilkaensis. 
Table 3. Phylogenetic affiliation of clones recovered from the midgut of $N$. chilkaensis.

\begin{tabular}{|c|c|c|c|c|}
\hline \multirow{2}{*}{$\begin{array}{l}\text { Taxon } \\
\text { No. }\end{array}$} & \multirow{2}{*}{$\begin{array}{c}\text { Clone } \\
\text { (Accession Number) }\end{array}$} & \multicolumn{3}{|c|}{ Closest Taxon } \\
\hline & & Description & $\begin{array}{l}\text { Accession } \\
\text { Number }\end{array}$ & $\begin{array}{c}\text { Similarity } \\
(\%)\end{array}$ \\
\hline 1 & $\begin{array}{l}\text { GNG-SV01 (FJ870510) } \\
\text { GNG-SV05 (FJ870548) } \\
\text { GNG-SV24 (FJ870526) } \\
\text { GNG-SV42 (FJ870539) } \\
\text { GNG-SV44 (FJ870541) }\end{array}$ & $\begin{array}{l}\text { 2,4-dichlorophenoxyacetic acid } \\
\text { degrading Cupriavidus sp. }\end{array}$ & EU827490 & $99.6-100.0$ \\
\hline 2 & $\begin{array}{l}\text { GNG-SV02 (FJ870511) } \\
\text { GNG-SV04 (FJ870512) } \\
\text { GNG-SV06 (FJ870514) } \\
\text { GNG-SV09 (FJ870517) } \\
\text { GNG-SV14 (FJ870520) } \\
\text { GNG-SV19 (FJ870509) } \\
\text { GNG-SV25 (FJ870527) } \\
\text { GNG-SV43 (FJ870540) }\end{array}$ & $\begin{array}{l}\text { Phyllobacterium sp. associated with } \\
\text { cyanobacterial blooms }\end{array}$ & AM989040 & $99.8-100.0$ \\
\hline 3 & $\begin{array}{l}\text { GNG-SV08 (FJ870516) } \\
\text { GNG-SV11 (FJ876833) } \\
\text { GNG-SV17 (FJ876832) } \\
\text { GNG-SV20 (FJ870523) } \\
\text { GNG-SV30 (FJ870530) } \\
\text { GNG-SV31 (FJ870531) }\end{array}$ & $\begin{array}{l}\text { Leifsonia sp. isolate capable of } \\
\text { degrading soluble organo-chromium } \\
\text { (III) complex }\end{array}$ & DQ901014 & $99.6-99.8$ \\
\hline 4 & $\begin{array}{l}\text { GNG-SV13 (FJ870519) } \\
\text { GNG-SV15 (FJ870521) } \\
\text { GNG-SV18 (FJ876831) } \\
\text { GNG-SV33 (FJ870545) } \\
\text { GNG-SV46 (FJ870543) }\end{array}$ & $\begin{array}{l}\text { Caulobacter sp. associated with } \\
\text { cyanobacterial blooms }\end{array}$ & AM989010 & $99.8-100.0$ \\
\hline 5 & $\begin{array}{l}\text { GNG-SV16 (FJ870522) } \\
\text { GNG-SV23 (FJ870525) } \\
\text { GNG-SV29 (FJ870544) } \\
\text { GNG-SV32 (FJ870532) } \\
\text { GNG-SV35 (FJ870533) } \\
\text { GNG-SV61 (FJ870537) }\end{array}$ & DEHP-degrading Gordonia sp. & DQ301916 & $98.3-99.8$ \\
\hline 6 & $\begin{array}{l}\text { GNG-SV27 (FJ870528) } \\
\text { GNG-SV36 (FJ870534) } \\
\text { GNG-SV39 (FJ870536) } \\
\text { GNG-SV41 (FJ870538) }\end{array}$ & $\begin{array}{l}\text { Dibenzothiophene-degrading } \\
\text { Agrobacterium tumefaciens }\end{array}$ & FJ425916 & $99.1-100.0$ \\
\hline 7 & $\begin{array}{l}\text { GNG-SV07 (FJ870515) } \\
\text { GNG-SV10 (FJ870518) } \\
\text { GNG-SV26 (FJ870547) } \\
\text { GNG-SV28 (FJ870529) } \\
\text { GNG-SV37 (FJ870535) }\end{array}$ & $\begin{array}{c}\text { Naphthalene utilizing Microbacterium } \\
\text { laeveniformis }\end{array}$ & AF535159 & 99.8 \\
\hline 8 & $\begin{array}{l}\text { GNG-SV21 (FJ876829) } \\
\text { GNG-SV47 (FJ876828) } \\
\text { GNG-SV91 (FJ876830) } \\
\text { GNG-SV112 (FJ870513) }\end{array}$ & PAH degrading Bacillus sp. & FJ449840 & 100.0 \\
\hline 9 & GNG-SV45 (FJ870542) & $\begin{array}{l}\text { Uncultured bacterial 16S rRNA clone } \\
\text { isolated from a algae-lysing culture }\end{array}$ & FJ667554 & 97.1 \\
\hline 10 & GNG-SV34 (FJ870546) & $\begin{array}{l}\text { Uncultured bacterium from nitric acid } \\
\text { contaminated waters }\end{array}$ & EF507913 & 95.6 \\
\hline 11 & GNG-SV12 (FJ976469) & $\begin{array}{l}\text { Uncultured bacterium from oil } \\
\text { contaminated soil }\end{array}$ & DQ984638 & 92.8 \\
\hline 12 & GNG-SV22 (FJ870524) & $\begin{array}{l}\text { Uncultured rhizospheric soil } \\
\text { bacterium }\end{array}$ & EU117091 & 93.7 \\
\hline
\end{tabular}


nearest phylogenetic relatives from GenBank and a dendrogram was constructed (Figure 2). Identical OTUs in the cultural studies were also detected in the culture-independent study. GNG-SV21, GNG-SV91, GNG-SV112 were found to belong to the same taxon of Bacillus sp. (FJ449840) as isolates GNG-AV4, GNG-AV6, GNGAV7, GNG-AV9, and GNG-AV12 (Table 2 and Table 3) covering 20.4 percent of the library. About 12 percent of the clone library matched with a Phyllobacterium sp. (AM989040), 7.4 percent with an Agrobacterium sp. (FJ425916), 11.1 percent with a DEHP-degrading Gordonia sp. (DQ301916), 10.1 percent with napthalene utilizing Microbacterium laeveniformis sp. (AF535159) and 12 percent with an organo-chromium complex degrading Leifsonia sp. (DQ901014). About 3.7 percent of the library (Table 3) matched uncultured entries on Genbank with $92.8 \%$ and $97.1 \%$ similarities. Having observed the presence of bacteria and clones matching with isolates capable of degrading recalcitrant hydrocarbons, it was decided to study the abilities of the isolates to degrade common aquatic pollutants.

\subsection{Recalcitrant Hydrocarbon Degrading Abilities of the Isolates}

Bacteria that are able to degrade hydrocarbons may use them as carbon source. Thirteen shortlisted isolates were tested for their abilities to grow with benz $(k)$ fluoranthene $(B(k) F)$, benz $(k)$ pyrene $(B(k) P)$, chrysene $(C H Y)$, dibenz (a,h) anthracene (DBA), fluorene (FLU), naphthalene (NAF), phenanthrene (PHE), pyrene (PYR) and 2,4,6-trichlorophenol (TCP), as sole carbon sources on mineral media agar plates and their growth is given in Table 4. Bacillus sp. GNG-AV7 and bacterium GNG-AV14 were unable to utilize any of these complex substrates. Isolate Staphylococcus sp. GNG-AV15 was able to utilize most of the PAHs, but failed to use TCP. Bacillus sp. GNG-AV4 and Bacillus sp. GNG-AV6 were also able to utilize majority of the PAHs. The only isolate that could utilize almost all the hydrocarbons tested including TCP, was GNV-AV8, belonging to Bacillus sp. (Table 4).

\subsection{Resistance and Production of Biosurfactant}

Although most of the bacteria isolated showed resistance to CTAB, only Kytococcus sp. GNG-AV13 and Staphylococcus sp. GNG-AV15 were found to be resistant to Triton-X100 (Table 5). It is recognized that the emulsification of the nonpolar hydrocarbon with water is the first step that helps bacteria to make hydrocarbons available as carbon source. Many of our isolates were found to be capable of producing biosurfactants. The amount of biosurfactant produced by each isolate was quantified after growth in Luria-Bertani broth for 24 hours. Only Bacillus sp. GNG-AV8 was found to reduce surface tension substantially, to $31.7 \pm 1.2 \mathrm{mN} / \mathrm{m}$ from an initial value of $60 \mathrm{mN} / \mathrm{m}$ for sterile medium (Table 6), while Bacillus species GNG-AV1, GNG-AV7, GNGAV11, G-AV12 and Staphylococcus sp. GNG-AV15 could be considered as mediocre biosurfactant-producers as compared to the former (Table 6).

\section{Discussion}

Recent surveys on polychaetes in the region of Mumbai [29]-[31] do not record the presence of Neanthes chilkaensis. The species of Nereids recorded from this region so far include Perinereis, Platynereis and Dendronereis [31]. The presence of $N$. chilkaensis to the tune of 85 percent of the Nereid population in Gorai was surprising. The species was not observed in any of our samplings from other areas of Mumbai waters. The present study was undertaken to understand the nature of the gut bacterial communities and to investigate their roles in alleviation of pollution stress of these hosts.

Keeping in mind the difficulties to culture some bacteria outside their native environment [28]-[30], we employed both cultivation-dependent and cultivation-independent molecular approaches. Cultivation dependent and independent findings have often been disparate with respect to Firmicutes and Actinobacteria [32]-[35] and the reasons attributed to such discrepancies are many. König [36] noted that Gram positive bacteria take part in early and intermediate steps of degradation. In this, the sporulating members may grow on plates but their inefficient lysis during DNA extraction may exclude them from being detected in the cultivation-independent study. On the other hand, more rigorous protocols for recovery of Gram-positive DNA could be successful at the cost of damage to Gram-negative DNA [37]. Nevertheless, these factors may lead to a biased under-representation of Gram-positive bacteria in clone libraries, especially felt in niches where their presence could be relevant.

Among the six individual hosts selected, a clear similarity was evident from the DGGE patterns (Figure 1). It is therefore likely that the community profile represents microbiota that survived in harsh gut microenvironment, 
Table 4. Ability of the isolates to degrade different Poly aromatic hydrocarbons (PAH).

\begin{tabular}{|c|c|c|c|c|c|c|c|c|}
\hline \multirow{2}{*}{ Isolate } & \multicolumn{8}{|c|}{ Carbon Sources } \\
\hline & $B(k) P$ & $D B A$ & PHE & $F L U$ & $\mathrm{CHY}$ & $N A F$ & $B(k) F$ & TCP \\
\hline AV1 & - & - & - & - & - & - & - & - \\
\hline AV4 & + & + & - & - & + & + & + & - \\
\hline AV5 & - & - & - & + & - & - & - & - \\
\hline AV6 & + & + & - & - & + & + & + & - \\
\hline AV7 & - & - & - & - & - & - & - & - \\
\hline AV8 & + & - & + & + & + & + & + & + \\
\hline AV9 & + & + & - & - & - & - & - & - \\
\hline AV10 & - & - & - & - & + & + & - & - \\
\hline AV11 & - & - & + & - & - & - & - & - \\
\hline AV12 & + & + & - & - & - & - & - & - \\
\hline AV13 & - & - & - & + & - & + & - & - \\
\hline AV14 & - & - & - & - & - & - & - & - \\
\hline AV15 & - & - & + & + & + & + & + & - \\
\hline
\end{tabular}

Benz(k)pyrene or B(k)P, dibenz(a,h)anthracene (DBA), Phenanthrene (PHE), Fluorene (FLU), Chrysene (CHY), Naphthalene (NAF), Benz(k)fluoranthene $(\mathrm{B}(\mathrm{k}) \mathrm{F})$; and 2,4,6-Trichlorophenol (TCP). PAH degraders $(+)$ and non-degraders $(-)$ are denoted.

Table 5. Surfactant resistance by isolates.

\begin{tabular}{|c|c|c|}
\hline Isolates & СТАВ $(100 \mu \mathrm{M})$ & Triton-X100 (0.1\%) \\
\hline GNG-AV1 & + & - \\
\hline GNG-AV2 & + & - \\
\hline GNG-AV3 & - & - \\
\hline GNG-AV4 & + & - \\
\hline GNG-AV5 & + & - \\
\hline GNG-AV6 & + & - \\
\hline GNG-AV7 & + & - \\
\hline GNG-AV8 & - & - \\
\hline GNG-AV9 & + & - \\
\hline GNG-AV10 & + & - \\
\hline GNG-AV11 & + & - \\
\hline GNG-AV12 & + & - \\
\hline GNG-AV13 & + & + \\
\hline GNG-AV14 & - & - \\
\hline GNG-AV15 & + & + \\
\hline
\end{tabular}

Growth (+): resistant; no-growth (-): sensitive.

suggesting that the residing (or attached) communities may not be a random mix of opportunists from each host's immediate environment. This lack of variability also provided the rationale for proceeding with a representative individual. Moreover, the 16S rRNA clone library generated can be considered to be representative of the residing bacterial assemblage in the midguts of the pollution-enduring $N$. chilkaensis populations of Gorai.

In this study, 53.7 percent of the clones match Gram-positive entries of GenBank (Table 3). At the same time all the isolates belong to members of Gram-positive groups i.e. Actinobacteria and Firmicutes, indicating a dominance of firmicutes in the midgut of $N$. chilkaensis. It was interesting to find about 20.4 percent of the clone library and $40 \%$ of the isolates matched with a PAH-degrading Bacillus isolate (FJ449840) (Table 3). 
Table 6. Surface tension (ST) and emulsification index (\%EI) of the culture supernatants of the midgut isolates, grown under identical conditions.

\begin{tabular}{cccc}
\hline Isolate & Surface Tension $(\mathbf{m N} / \mathbf{m})^{\mathbf{a}}$ & \% Reduction in Surface Tension $^{\mathbf{a}}$ & Emulsification Index (\%EI) $^{\text {(\%) }}$ \\
\hline GNG-AV1 & $51 \pm 1.7$ & 19.05 & 0 \\
GNG-AV4 & $52.3 \pm 0.6$ & 16.98 & 0 \\
GNG-AV 5 & $56.3 \pm 0.6$ & 10.63 & 0 \\
GNG-AV6 & $52.7 \pm 0.6$ & 16.35 & 0 \\
GNG-AV7 & $49.7 \pm 1.2$ & 21.11 & 41.67 \\
GNG-AV8 & $31.7 \pm 1.2$ & 49.68 & 0 \\
GNG-AV9 & $55 \pm 1.7$ & 12.70 & 0 \\
GNG-AV10 & $55.3 \pm 0.6$ & 12.22 & 0 \\
GNG-AV11 & $51.7 \pm 1.5$ & 17.94 & 0 \\
GNG-AV12 & $51.3 \pm 0.6$ & 18.57 & 0 \\
GNG-AV13 & $60.7 \pm 0.6$ & 3.65 & 34.78 \\
GNG-AV14 & $61 \pm 1.7$ & 3.65 & 25 \\
GNG-AV15 & $47.3 \pm 0.6$ & 24.92 & 0 \\
\hline
\end{tabular}

${ }^{\text {a }}$ The surface tension of the uninoculated medium was $63 \pm 0.4 \mathrm{mN} / \mathrm{m}$, with freshly inoculated broth having values within the same range.

Few isolates (Table 2), did not represent the clone library were Staphylococcus isolate (GNG-AV15) and Kytococcus isolate (GNG-AV13). As expected many of the isolates are reported as cultured and uncultured members from other marine invertebrates (Table 2).

The GenBank relatives of Leifsonia, Microbacterium and Gordonia detected by the cultivation-independent approach are reported to have unique degradative abilities (Table 3). None of them, however, were present among the cultured isolates (Table 2). Interestingly, these three entries also happen to be close phylogenetic relatives of three PAH-utilizing isolates from a previous study [38]. It is probable that we have missed some bacteria belonging to Actinobacteria phylum in the culturable study because the selective procedures such as heattreatment and incorporation of specific substrates necessary for isolation of actinomycetes, were not used. In similar studies of Nereid midgut phylogeny Li et al. [8] observed only two Gram positive bacteria (Clostridium species).

While Gram-negative matches constituted about 43 percent of the clone library, none of the midgut isolates was Gram negative. One of the two other Gram-negative clusters in the clone library matches a dibenzothiophene-degrading Agrobacterium tumefaciens and a 2,4-dichlorophenoxyacetic acid degrading Cupriavidus strain representing $7.4 \%$ and $11.1 \%$ of the clonal library respectively (Table 3). The slow growth of these $\alpha$-proteobacterial members might have resulted in their absence on plate as indicated by previous workers [32] [39].

The Gorai mudflats have become deeply affected by the dumping of wastes directly into the sea, pushing the system to the brink of crisis [13]. Since the polychaete $N$. chilkaensis were collected from polluted mudflats of Gorai, Mumbai, we have tried to characterize the culturable flora by their abilities to utilize common polyaromatic hydrocarbon pollutants like dibenz(a,h)anthracene, benz(k)pyrene, benz(k)fluoranthene, chrysene, fluorene, naphthalene, and phenanthrene. These chemicals are known to find their way to Gorai mudflat due to idol immersion [12], from ferries [13] or may come from the industrial belt located upstream. We also tested the abilities of the isolates to utilize 2,4,6-trichlorophenol alongside a range of PAHs because Trichlorophenols such as 2,4,6-trichlorophenol, is widely used by pesticide, glue and the textile industries and had a strong chance of being present in Gorai originating from the small and medium industries located along Gorai creek. Of all the isolates checked for their ability to utilize 2,4,6-trichlorophenol, only Bacillus sp. GNG-AV8 was found to be positive (Table 4).

Many of the midgut isolates (84\%) were able to utilize PAHs as sole carbon sources (Table 4). The factors governing PAH utilization by degradative organisms range from the efficiency of uptake mechanisms to the ability to enhance the availability of the compound by biosurfactant and bioemulsifier production [40]-[42]. Nereid guts are shown to have high concentrations of surfactants with numerous chemical structures [9]. While bacteria are known to produce biosurfactants, it is still not clear whether the source of these surfactants is the gut 
microbial community [43]. As was seen in these results, most of the isolates were resistant to cationic surfactant CTAB, an antiseptic Cetrimide while only few were resistant to non-ionic surfactant Triton-X100 (Table 5). Klosterhaus \& Baker [44] studied the role of surfactant micelles in the absorption of chlorinated hydrocarbons and polyaromatic hydrocarbons in polychaete gut. Their study indicates that absorption requires presence of surfactant micelles to solubilize hydrocarbons in gut fluid. About 77 percent of the isolates in the present study were found to considerably reduce the surface tension of Luria Bertani Broth (to or below $55 \mathrm{mN} / \mathrm{m}$ ), with identical conditions of growth (Table 6) when checked with cell-free extracts. In comparison to Bacillus sp. GNG-AV8 (Table 6), which was able to reduce the surface tension of LB broth by about 49.68 percent, the other isolates can be regarded as mediocre biosurfactant producers with the ability to reduce surface tension in the range of 12.22 to 24.92 percent. From this study it is clear that these isolates could not only utilize the PAHs as carbon source but also produced biosurfactant to make these hydrophobic substances available for degradation. The GNV-AV8 that exceeded other isolates in its biodegradation capabilities was also a better biosurfactant producer. This indicates that degradation is probably related to biosurfactant producing ability. The PAH utilizing bacteria might depend on other bacteria for biosurfactant, but it enhances its independence if they do both the activities. Klosterhaus \& Baker [44] reported the likely requirement of micelles in solubilization of sediment bound hydrophobic organic compounds (HOCs) before accumulation in Nereis virens gut having high amounts of surfactants in their gut fluids. Although the cultivation-independent detection of 16S rRNA sequences of various degradative strains from other studies does not necessarily prove their functional relevance, it is interesting to note that a majority of the clones (72.1 percent) detected in the gut of $N$. chilkaensis, match closely with GenBank entries of many aromatic pollutant degraders or organisms isolated from contaminated sites (Table 3). Evidence from the cultural studies supports the ability of the midgut isolates to degrade a complex array of aromatic recalcitrants with the help of their abilities to produce surfactants. The nature of the bacterial members, specifically the predominance of degraders in the gut community, indicates possible selection of microbial community in the gut of $N$. chilkaensis with respect to pollution.

Although these benthic organisms have been studied as pollution indicators, their gut flora can yield interesting microorganisms with immense application potential.

The Circle branch tree is further shown in three separate clusters of branches. The sequences were first aligned using the CLUSTALW program and a neighbour-joining tree was generated using the Kimura-2 parameter method for computing the evolutionary distances. E. coli positions 93 - 653 were considered for the analysis. The numbers at the nodes indicate the bootstrap values based on 1000 replicates. The small bar indicates the Jukes-Cantor evolutionary distance. The GNG-AV series represent cultured isolates and the GNG-SV series represent the clones from the culture-independent study. The rest of the members are closest-neighbour matches as recovered from BLAST searches on the GenBank database.

\section{Acknowledgements}

The authors gratefully acknowledge the help rendered by Dr. B. Suresh at the Maharaja Sayajirao University (MSU) of Baroda for identifying the specimens used in our study; Dr. A. S. Nerurkar of MSU for the use of laboratory facilities; and Mr. A. K. Padmanabhan and Mr. J. M. Koli of CIFE for technical assistance.

\section{References}

[1] Grizzle, R.E. (1984) Pollution Indicator Species of Macrobenthos in a Coastal Lagoon. Marine Ecology Progress Series, 18, 191-200. http://dx.doi.org/10.3354/meps018191

[2] Gomes, T., Gonzalez-Rey, M., Rodríguez-Romero, A., Trombini, C., Riba, I., Blasco, J. and Bebianno, M.J. (2013) Biomarkers in Nereis diversicolor (Polychaeta: Nereididae) as Management Tools for Environmental Assessment on the Southwest Iberian Coast. Scientia Marina, 77, 69-78. http://dx.doi.org/10.3989/scimar.03731.27F

[3] Read, G.; Fauchald, K. (Ed.) (2014) World Polychaeta Database. http://www.marinespecies.org/polychaeta

[4] Blaise, C., Gagné, F., Gillis, P.L. and Eullaffroy, P. (2013) Polychaetes as Bioindicators of Water Quality in the Saguenay Fjord (Quebec, Canada): A Preliminary Investigation. Journal of Xenobiotics, 3, e1. http://dx.doi.org/10.4081/xeno.2013.s1.e1

[5] Šyvokiene, J. and Mickënienë, L. (2002) Change in the Intestinal Microflora of Molluscs from the Neris River Depending on Pollution. Acta Zoologica Lituanica, 12, 76-81. http://dx.doi.org/10.1080/13921657.2002.10512490

[6] Leahy, J.G. and Colwell, R.R. (1990) Microbial Degradation of Hydrocarbons in the Environment. Microbiological 
Reviews, 54, 305-315.

[7] Schmitt, H., Van Beelen, P., Tolls, J. and Van Leeuwen, C.L. (2004) Pollution-Induced Community Tolerance of Soil Microbial Communities Caused by the Antibiotic Sulfachloropyridazine. Environmental Science and Technology, 38, 1148-1153. http://dx.doi.org/10.1021/es034685p

[8] Li, M., Yang, H. and Gu, J.-D. (2009) Phylogenetic Diversity and Axial Distribution of Microbes in the Intestinal Tract of the Polychaete Neanthes glandicincta. Microbial Ecology, 58, 892-902. http://dx.doi.org/10.1007/s00248-009-9550-8

[9] Plante, C.J., Coe, K.M. and Plante, R.G. (2008) Isolation of Surfactant-Resistant Bacteria from Natural, Surfactant-Rich Marine Habitats. Applied and Environmental Microbiology, 74, 5093-5099. http://dx.doi.org/10.1128/AEM.02734-07

[10] Vijay, R., Sardar, V.K., Dhage, S.S., Kelkar, P.S. and Gupta, A. (2010) Hydrodynamic Assessment of Sewage Impact on Water Quality of Malad Creek, Mumbai, India. Environmental Monitoring and Assessment, 165, 559-571. http://dx.doi.org/10.1007/s10661-009-0967-9

[11] Jaiswar, A.K., Kulkarni, B.G. and Chakraborty, S.K. (2006) Assessment of Coastal Pollution through Bioassay and Transplantation of Intertidal Clams. Journal of Environmental Science and Engineering, 48, 119-122.

[12] Vyas, A., Bajpai, A. and Verma, N. (2008) Water Quality Improvement after Shifting of Idol Immersion Site: A Case Study of Upper Lake, Bhopal, India. Environmental Monitoring and Assessment, 145, 437-443. http://dx.doi.org/10.1007/s10661-007-0052-1

[13] Choudhury, A.R. (2000) Amusement Parks versus People’s Livelihood. Economic and Political Weekly, 35, 32863288.

[14] Broderick, N.A., Goodman, R.M., Raffa, K.F. and Handelsman, J. (2000) Synergy between Zwittermicin A and Bacillus thuringiensis subsp. Kurstaki against Gypsy Moth (Lepidoptera: Lymantriidae). Environmental Entomology, 29, 101-107. http://dx.doi.org/10.1603/0046-225X-29.1.101

[15] Neumann, B., Pospiech, A. and Schairer, H.U. (1992) Rapid Isolation of Genomic DNA from Gram-Negative Bacteria. Trends in Genetics, 8, 332-333. http://dx.doi.org/10.1016/0168-9525(92)90269-A

[16] Muyzer, G., De Waal, E.C. and Uitterlinden, A.G. (1993) Profiling of Complex Microbial Populations by Denaturing Gradient Gel Electrophoresis Analysis of Polymerase Chain Reaction-Amplified Genes Coding for 16S rRNA. Applied and Environmental Microbiology, 59, 695-700.

[17] Krebs, C.J. (1999) Ecological Methodology. 2nd Edition, Addison Wesley Longman, Menlo Park, 620.

[18] Marchesi, J.R., Sato, T., Weightman, A.J., Martin, T.A., Fry, J.C., Hiom, S.J. and Wade, W.G. (1998) Design and Evaluation of Useful Bacterium-Specific PCR Primers that Amplify Genes Coding for Bacterial 16S rRNA. Applied and Environmental Microbiology, 64, 795-799.

[19] Altschul, S.F., Gish, W., Miller, W., Myers, E.W. and Lipman, D.J. (1990) Basic Local Alignment Search Tool. Journal of Molecular Biology, 215, 403-410. http://dx.doi.org/10.1016/S0022-2836(05)80360-2

[20] Tamura, K., Dudley, J., Nei, M. and Kumar, S. (2007) MEGA4: Molecular Evolutionary Genetics Analysis (MEGA) Software Version 4.0. Molecular Biology and Evolution, 24, 1596-1599. http://dx.doi.org/10.1093/molbev/msm092

[21] Saitou, N. and Nei, M. (1987) The Neighbor-Joining Method: A New Method for Reconstructing Phylogenetic Trees. Molecular Biology and Evolution, 4, 406-425.

[22] Lane, D.J., Pace, B., Olsen, G.J., Stahl, D.A., Sogin, M.L. and Pace, N.R. (1985) Rapid Determination of 16S Ribosomal RNA Sequences for Phylogenetic Analyses. Proceedings of the National Academy of Sciences of the United States of America, 82, 6955-6959. http://dx.doi.org/10.1073/pnas.82.20.6955

[23] Schmidt, T.M., DeLong, E.F. and Pace, N.R. (1991) Analysis of a Marine Picoplankton Community by 16S rRNA Gene Cloning and Sequencing. Journal of Bacteriology, 173, 4371-4378.

[24] Juhasz, A.L., Britz, M.L. and Stanley, G.A. (1997) Degradation of Fluoranthene, Pyrene, Benz[a]anthracene and dibenz[a, h]Anthracene by Burkholderia cepacia. Journal of Applied Microbiology, 83, 189-198. http://dx.doi.org/10.1046/j.1365-2672.1997.00220.x

[25] Li, D.Y., Eberspächer, J., Wagner, B., Kuntzer, J. and Lingens, F. (1991) Degradation of 2, 4, 6-trichlorophenol by Azotobacter sp. Strain GP1. Applied and Environmental Microbiology, 57, 1920-1928.

[26] Youssef, N.H., Duncan, K.E., Nagle, D.P., Savage, K.N., Knapp, R.M. and McInerney, M.J. (2004) Comparison of Methods to Detect Biosurfactant Production by Diverse Microorganisms. Journal of Microbiological Methods, 56, 339-347. http://dx.doi.org/10.1016/j.mimet.2003.11.001

[27] Markande, A.R., Acharya, S.R. and Nerurkar, A.S. (2013) Physicochemical Characterization of a Thermostable Glycoprotein Bioemulsifier from Solibacillus silvestris AM1. Process Biochemistry, 48, 1800-1808. http://dx.doi.org/10.1016/j.procbio.2013.08.017

[28] Good, I.J. (1953) The Population Frequencies of Species and the Estimation of Population Parameters. Biometrika, 40, 
237-264. http://dx.doi.org/10.1093/biomet/40.3-4.237

[29] Holland, G. (2009) Ocean Biogeographic Information System (OBIS). http://hdl.handle.net/1834/3010

[30] Ingole, B., Sivadas, S., Nanajkar, M., Sautya, S. and Nag, A. (2009) A Comparative Study of Macrobenthic Community from Harbours along the Central West Coast of India. Environmental Monitoring and Assessment, 154, 135-146. http://dx.doi.org/10.1007/s10661-008-0384-5

[31] Sukumaran, S. and Sarala Devi, K. (2009) Polychaete Diversity and Its Relevance in the Rapid Environmental Assessment of Mumbai Port. Current Science, 97, 1439-1444.

[32] Ellis, R.J., Morgan, P., Weightman, A.J. and Fry, J.C. (2003) Cultivation-Dependent and -Independent Approaches for Determining Bacterial Diversity in Heavy-Metal-Contaminated Soil. Applied and Environmental Microbiology, 69, 3223-3230. http://dx.doi.org/10.1128/AEM.69.6.3223-3230.2003

[33] Kaiser, O., Pühler, A. and Selbitschka, W. (2001) Phylogenetic Analysis of Microbial Diversity in the Rhizoplane of Oilseed Rape (Brassica napus cv. Westar) Employing Cultivation-Dependent and Cultivation-Independent Approaches. Microbial Ecology, 42, 136-149.

[34] Olofsson, T.C., Ahrné, S. and Molin, G. (2007) Composition of the Bacterial Population of Refrigerated Beef, Identified with Direct 16S rRNA Gene Analysis and Pure Culture Technique. International Journal of Food Microbiology, 118, 233-240. http://dx.doi.org/10.1016/j.ijfoodmicro.2007.07.017

[35] Stougaard, P., Jørgensen, F., Johnsen, M.G. and Hansen, O.C. (2002) Microbial Diversity in Ikaite Tufa Columns: An Alkaline, Cold Ecological Niche in Greenland. Environmental Microbiology, 4, 487-493. http://dx.doi.org/10.1046/j.1462-2920.2002.00327.x

[36] König, H. (2006) Bacillus Species in the Intestine of Termites and Other Soil Invertebrates. Journal of Applied Microbiology, 101, 620-627. http://dx.doi.org/10.1111/j.1365-2672.2006.02914.x

[37] Wintzingerode, F.V., Göbel, U.B. and Stackebrandt, E. (1997) Determination of Microbial Diversity in Environmental Samples: Pitfalls of PCR-Based rRNA Analysis. FEMS Microbiology Reviews, 21, 213-229. http://dx.doi.org/10.1111/j.1574-6976.1997.tb00351.x

[38] Jacques, R.J.S., Okeke, B.C., Bento, F.M., Peralba, M.C.R. and Camargo, F.A.O. (2009) Improved Enrichment and Isolation of Polycyclic Aromatic Hydrocarbons (PAH)-Degrading Microorganisms in Soil Using Anthracene as a Model PAH. Current Microbiology, 58, 628-634. http://dx.doi.org/10.1007/s00284-009-9381-3

[39] Mitsui, H., Gorlach, K., Lee, H., Hattori, R. and Hattori, T. (1997) Incubation Time and Media Requirements of Culturable Bacteria from Different Phylogenetic Groups. Journal of Microbiological Methods, 30, 103-110. http://dx.doi.org/10.1016/S0167-7012(97)00052-3

[40] Bastiaens, L., Springael, D., Wattiau, P., Harms, H., Verachtert, H. and Diels, L. (2000) Isolation of Adherent Polycyclic Aromatic Hydrocarbon (PAH)-Degrading Bacteria Using PAH-Sorbing Carriers. Applied and Environmental Microbiology, 66, 1834-1843. http://dx.doi.org/10.1128/AEM.66.5.1834-1843.2000

[41] Bodour, A.A., Drees, K.P. and Maier, R.M. (2003) Distribution of Biosurfactant-Producing Bacteria in Undisturbed and Contaminated Arid Southwestern Soils. Applied and Environmental Microbiology, 69, 3280-3287. http://dx.doi.org/10.1128/AEM.69.6.3280-3287.2003

[42] Desai, J.D. and Banat, I.M. (1997) Microbial Production of Surfactants and Their Commercial Potential. Microbiology and Molecular Biology Reviews, 61, 47-64.

[43] Weston, D.P. and Mayer, L.M. (1998) Comparison of in Vitro Digestive Fluid Extraction and Traditional in Vivo Approaches as Measures of Polycyclic Aromatic Hydrocarbon Bioavailability from Sediments. Environmental Toxicology and Chemistry, 17, 830-840. http://dx.doi.org/10.1897/1551-5028(1998)017<0830:COIVDF>2.3.CO;2

[44] Klosterhaus, S.L. and Baker, J.E. (2010) Bioavailability of Decabromodiphenyl Ether to the Marine Polychaete Nereis virens. Environmental Toxicology and Chemistry, 29, 860-868. http://dx.doi.org/10.1002/etc.103 
Scientific Research Publishing (SCIRP) is one of the largest Open Access journal publishers. It is currently publishing more than 200 open access, online, peer-reviewed journals covering a wide range of academic disciplines. SCIRP serves the worldwide academic communities and contributes to the progress and application of science with its publication.

Other selected journals from SCIRP are listed as below. Submit your manuscript to us via either submit@scirp.org or Online Submission Portal.
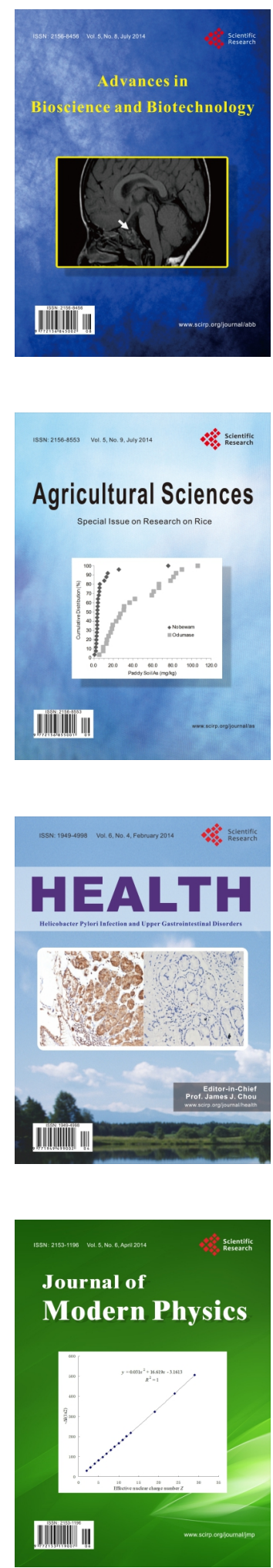
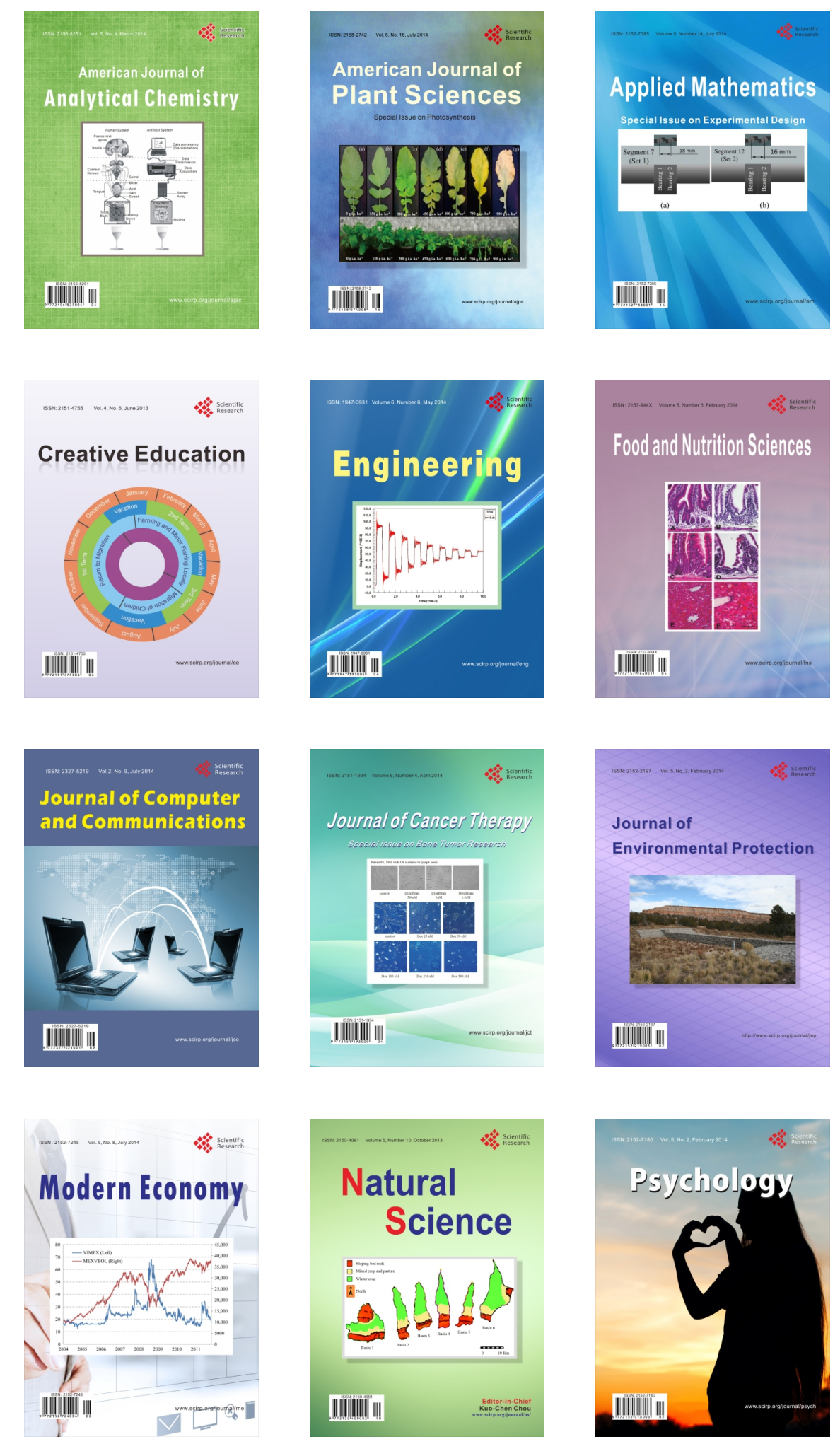